\title{
Two Siblings with Isolated GH Deficiency Due to Loss-of-Function Mutation in the GHRHR Gene: Successful Treatment with Growth Hormone Despite Late Admission and Severe Growth Retardation
}

\author{
Zeynep Şıklar¹, Merih Berberoğlu¹, Maria Legendre2, Serge Amselem², Olcay Evliyaoğlu¹, \\ Bülent Hacıhamdioğlu1, Şenay Savaş Erdeve1, Gönül Öçal ${ }^{1}$ \\ ${ }^{1}$ Ankara University, School of Medicine, Department of Pediatric Endocrinology, Ankara, Turkey \\ ${ }^{2}$ Service de Genetique Medicale, Hopital Armand-Trousseau, Paris F-75012 France; Inserm U933, Hopital Armand-Trousseau, Paris F-75012 France
}

\begin{abstract}
Patients with growth hormone releasing hormone receptor (GHRHR) mutations exhibit pronounced dwarfism and are phenotypically and biochemically indistinguishable from other forms of isolated growth hormone deficiency (IGHD). We presented here two siblings with clinical findings of IGHD due to a nonsense mutation in the GHRHR gene who reached their target height in spite of late GH treatment. Two female siblings were admitted to our clinic with severe short stature at the age of 13.8 (patient 1) and 14.8 years (patient 2). On admission, height in patient 1 was $107 \mathrm{~cm} \mathrm{(-8.6}$ $\mathrm{SD})$ and $117 \mathrm{~cm}(-6.7 \mathrm{SD})$ in patient 2. Bone age was delayed in both patients ( 6 years and 9 years). Clinical and biochemical analyses revealed a diagnosis of complete IGHD (peak GH levels on stimulation test was $0.06 \mathrm{ng} / \mathrm{mL}$ in patient 1 and $0.16 \mathrm{ng} / \mathrm{mL}$ in patient 2). Patients were given recombinant human GH treatment. Genetic analysis of the GH and GHRHR genes revealed that both patientscarried the GHRHR gene mutation p.Glu72X (c.214 G>T) in exon 3 in homozygous (or hemizygous) state. After seven years of $\mathrm{GH}$ treatment, the patients reached a final height appropriate for their target height. Final height was $151 \mathrm{~cm}(-1.5 \mathrm{SD})$ in patient 1 and $153 \mathrm{~cm}(-1.2 \mathrm{SD})$ in patient 2. In conclusion, genetic analysis is indicated in IGHD patients with severe growth failure and a positive family history. In spite of the very late diagnosis in these two patients who presented with severe growth deficit due to homozygous loss-of-function mutations in GHRHR, their final heights reached the target height.
\end{abstract}

Key words: GHRHR mutation, final height, transition, GH deficiency

Conflict of interest: None declared

Received: 03.10.2010

Accepted: 10.11.2010

\section{Introduction}

Growth hormone deficiency (GHD) is usually sporadic and may be a result of environmental cerebral insults or developmental anomalies. However, 3-30\% of growth hormone (GH) deficient cases have an affected first-degree relative, suggesting a genetic etiology (1). Familial isolated growth hormone deficiency (IGHD) can result from genetic defects in genes encoding the $\mathrm{GH}$, the $\mathrm{GH}$ secretagogue receptor, or the GH-releasing hormone receptor (GHRHR). It has been estimated that the mutations in the human GHRHR gene cause approximately $10 \%$ of autosomal recessive familial IGHD cases (2).

Patients with GHRHR mutations have marked dwarfism transmitted in a recessive fashion, and are phenotypically and biochemically indistinguishable from other forms of IGHD.

Regardless of etiology, early GH therapy in GHD children aims to prevent neonatal hypoglycemia and contribute to the attainment of better adult height. Age at initiation of $\mathrm{GH}$ treatment is one of the variables that influence final height (3).

We present here two siblings with clinical findings of IGHD due to a nonsense mutation in the GHRHR gene who responded well to $\mathrm{GH}$ therapy despite late admission.

Address for Correspondence

Zeynep Şıklar, Ankara University School of Medicine, Department of Pediatric Endocrinology, Ankara, Turkey Gsm: +90 5053422169 E-mail: zeynepsklr@gmail.com

(๑) Journal of Clinical Research in Pediatric Endocrinology, Published by Galenos Publishing. 


\section{Patients}

Two female siblings were admitted to our clinic with severe short stature at the age of 13.8 (patient 1) and 14.8 years (patient 2) (Figure 1). On admission, patient 1 measured $107 \mathrm{~cm}(-8.6 \mathrm{SD})$ in height, and patient $2117 \mathrm{~cm}$ $(-6.74 \mathrm{SD})$. Bone age was delayed in both patients (corresponding to ages 6 years and 9 years at 13.8 and 14.8 years, respectively). Birth weight was $3000 \mathrm{~g}$ in patient 1 and $3200 \mathrm{~g}$ in patient 2. No history of neonatal hypoglycemia was reported. Their target height was 153 $\mathrm{cm}$ (-1.18 SD). Their parentally adjusted height deficits were -7.42 SD and -5.56 SD respectively.

Clinical examination revealed minimal midfacial hypoplasia with frontal bossing, depressed nasal bridge, abdominal obesity, high-pitched voice, and depressive behavior in addition to severe short stature (Figure 2). Both children were prepubertal and their level of intelligence appeared to be normal. Biochemichal analysis revealed very low levels of insulin-like growth factor-1 (IGF-1) and IGF-binding protein-3 (IGFBP-3), dyslipidemia, low basal $\mathrm{GH}$, normal thyroid function tests, and normal levels of cortisol, adrenocorticotropic hormone (ACTH) and prolactin (Table 1). Insulin-induced hypoglycemia and L-Dopa stimulation tests were applied to the patients as $\mathrm{GH}$ stimulation tests. $\mathrm{GH}$ levels in response to stimulation tests were very low and set the diagnosis of severe complete IGHD in both patients.

Magnetic resonance imaging (MRI) showed anterior pituitary hypoplasia in both sisters. Treatment was initiated with recombinant human $\mathrm{GH}(\mathrm{rhGH})$ in a dose of $0.2 \mathrm{mg} / \mathrm{kg} /$ week administered as a daily subcutaneous

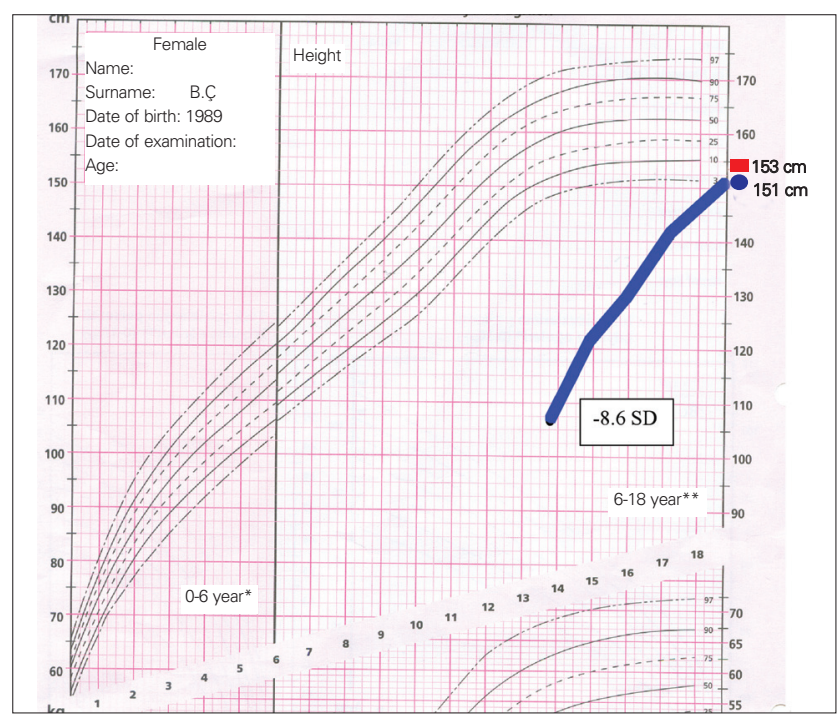

Figure 1. a) Growth chart of patient 1 ; $\boldsymbol{\square}$ target height $\bullet$ final height injection. Chronological age was 13.9 years in patient 1 and 14.8 years-in patient 2 .

During follow-up, onset of puberty was noted at 15.6 years in patient 1 and at 15.3 years in patient 2 . Bone ages were 8 years 10 months in both patients at pubertal onset. Patient 2 received gonadotropin-releasing hormone analog $(\mathrm{GnRHa})$ therapy in order to delay puberty and extend the beneficial effect of $\mathrm{GH}$ treatment on height gain. However, after one year of $\mathrm{GnRHa}$ treatment, no pubertal or bone age arrest was observed (bone age increased from 8 years 10 months to 12 years in one year), and GnRHa therapy was stopped. Menarche occurred at age 18.16 years in patient 1 and at 19.5 years in patient 2. Maternal menarcheal age was not precise. After seven years of $\mathrm{GH}$ treatment, patients reached their target height. Final height was $151 \mathrm{~cm}(-1.52 \mathrm{SD})$ in patient 1 and $153 \mathrm{~cm}$ (-1.18 SD) in patient 2 (Figure 2).

Genetic investigation included analysis of the $\mathrm{GH}$ and GHRHR genes, which revealed that both patients carry a GHRHR gene mutation p.Glu72X (c.214 G>T) in exon 3 in homozygous (or hemizygous) state.

\section{Discussion}

Familial IGHD is associated with at least four distinct forms (4). Two forms show autosomal recessive inheritance (IGHD type 1A and 1B), one form has autosomal dominant inheritance (IGHD type 2), and one is X-linked (IGHD type 3). Type 1B is the most frequently encountered form and could result from genetic defects in either GH gene or GHRHR gene (5). The GHRHR gene encodes a 423-aminoacid receptor protein and is essential for $\mathrm{GHRH}$-stimulated secretion of $\mathrm{GH}(6)$.

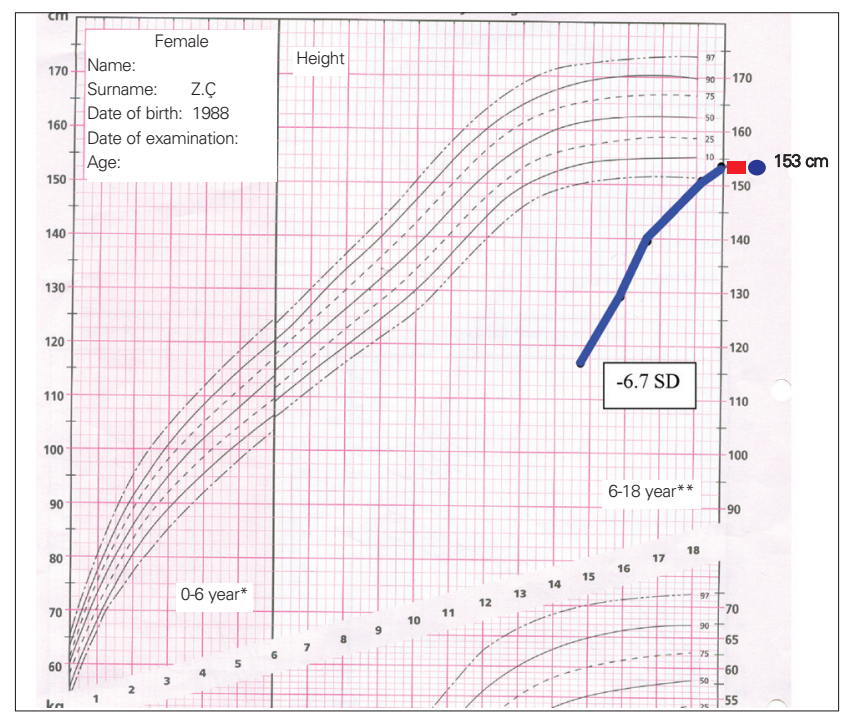

Figure 1. b) Growth chart of patient 2; $\boldsymbol{a}$ target height final height 
GHRHR gene defects are recognized as the cause of approximately $10 \%$ of autosomal recessive IGHD cases (2).

GHRHR mutations reported to date include six splice site mutations, two microdeletions, two nonsense mutations, seven missense mutations, and one in the

\begin{tabular}{|c|c|c|}
\hline & Patient 1 & Patient 2 \\
\hline Basal GH (ng/mL) & 0.1 & 0.0 \\
\hline $\begin{array}{l}\text { Peak GH after insulin-induced } \\
\text { hypoglycemia }(\mathrm{ng} / \mathrm{mL})(\mathrm{n}>10)\end{array}$ & 0.1 & 0.0 \\
\hline Peak GH after L-DOPA test $(\mathrm{ng} / \mathrm{mL})(\mathrm{N}>10)$ & 0.1 & 0.2 \\
\hline Basal IGF-1 (ng/mL) & 7.5 (-4.8 SD) & $4.2(-5.3 \mathrm{SD})$ \\
\hline Basal IGFBP-3 (ng/mL) & $626(-6.1 \mathrm{SD})$ & 612 (-6.3 SD) \\
\hline fT4 (pmol/L) (N: 11-22) & 15.6 & 21.6 \\
\hline TSH (mIU/mL) (N: 0.5-5) & 4.2 & 3.1 \\
\hline Cortisol (mcg/dl) (N: 5-23) & 23.3 & 21.1 \\
\hline ACTH $(\mathrm{pg} / \mathrm{mL})(\mathrm{N}: 5-50)$ & 33.5 & 27.5 \\
\hline Basal LH (mlU/mL) & 0.2 & 0.2 \\
\hline Stimulated LH (mIU/mL) & 2.6 & 6.8 \\
\hline Prolactin (ng/mL) (N:3.4-24) & 26.9 & 35.6 \\
\hline Total cholesterol $(\mathrm{mg} / \mathrm{dL})(\mathrm{N}:<200)$ & 233 & 218 \\
\hline HDL-C (mg/dL) (N: >40) & 45 & 52 \\
\hline LDL-C (mg/dL) (N: <100) & 157 & 139 \\
\hline VLDL-C (mg/dl) (N:<30) & 31 & 27 \\
\hline Triglycerides (mg/dL) $(\mathrm{N}<130)$ & 153 & 136 \\
\hline \multicolumn{3}{|c|}{$\begin{array}{l}\text { GH: growth hormone; IGF-1: insulin like growth factor-1; IGFBP-3: } \\
\text { IGF binding protein-3; ACTH: adrenocorticotropic hormone; LH: Luteinizing hormone; } \\
\text { FSH: follicle stimulating hormone }\end{array}$} \\
\hline
\end{tabular}

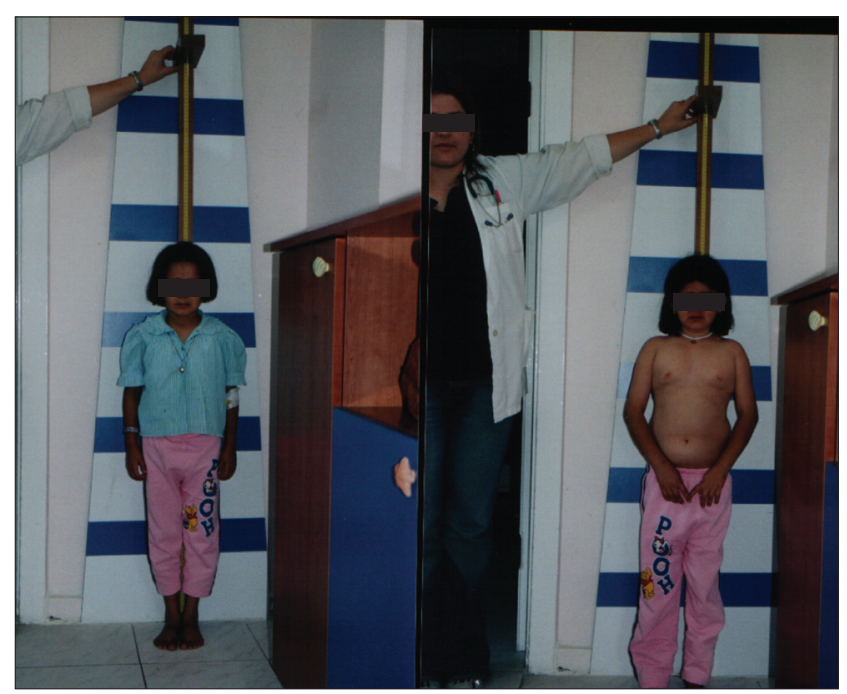

Figure 2. a) Two sister with GH-releasing hormone receptor (GHRHR) gene mutation: before treatment promoter gene $(7,8,9,10)$. Our patients carried the GHRHR gene nonsense mutation p.Glu72X (c.214 G>T) in exon 3. Most cases with this same mutation originated from Asia, especially from India or Sri Lanka $(11,12)$.

Characteristics of patients with GHRHR mutations are very similar to those with $\mathrm{GH}$ gene defects. Patients carrying GHRHR mutations usually have high-pitched voices, increased abdominal fat, very short but normally proportioned stature, normal intelligence, minimal facial hypoplasia, very low levels of GH and IGF-1, and anterior pituitary hypoplasia on MRI $(13,14)$. Fertility is usually not affected, but puberty is reported to be delayed, especially in male patients (15). The female patients described herein showed similar characteristics of severe GHD.

Both patients had anterior pituitary hypoplasia on MRI. Mutations in GHRHR are usually associated with anterior pituitary hypoplasia but normally placed posterior pituitary on MRI. Given the important role of $\mathrm{GHRH}$ in regulating the proliferation and function of somatotroph cells, abnormalities in the GHRHR has been expected to cause anterior pituitary hypoplasia (13).

The aim of $\mathrm{GH}$ treatment is to avoid neonatal hypoglycemia and to attain better adult height. Our patients had no history of neonatal hypoglycemia. Late admission of patients with severe growth retardation is one important factor that compromises height increment. Early recognition of GHD is essential for an optimal height outcome (16). At admission, our patients were very short and their ages were not very young. It is known that final height is correlated with height for chronological age at diagnosis (3) the higher the chronological age, the lower the final height reached by the patients. One important factor in evaluating response to $\mathrm{GH}$ therapy is extent of attainment of the

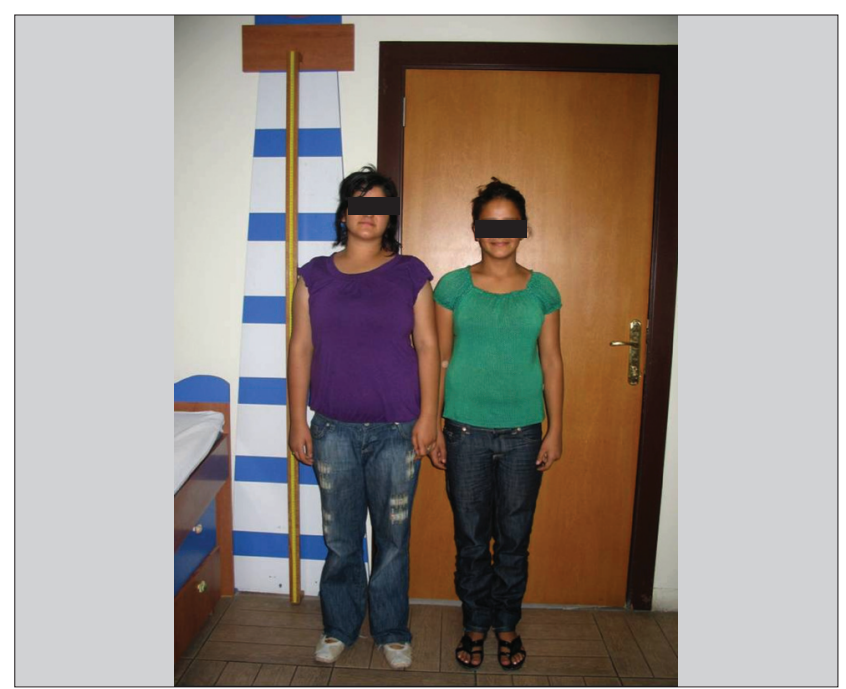

Figure 2. b) Patients with $\mathrm{GH}$-releasing hormone receptor (GHRHR) mutation: after treatment 
patient's genetic targeted height. Our patients achieved their target height despite the very late age at diagnosis. In addition to age at diagnosis, compliance to $\mathrm{GH}$ therapy, late onset of puberty and slow pubertal maturation may be important factors in attainment of a satisfactory final height. Patient 1 entered puberty at age of 15.6 years and patient 2 - at 15.3 years. The duration of puberty was also normal, being 2.6 years in patient 1 and 4.3 years in patient 2 . however use of $\mathrm{GnRHa}$ in patient 2 might have modified the duration of puberty. In addition, the severe degree of GHD in our patients may have affected the height gain. It is well known that growth rates correlate inversely with peak $\mathrm{GH}$ levels. The more severe the $\mathrm{GH}$ deficit is, the better the growth response is to $\mathrm{GH}(17)$.

In conclusion, genetic defects in related genes should be suspected in IGHD patients with severe growth failure and a positive family history, and molecular studies are indicated in such patients. In spite of the very late admission of these patients with severe growth deficit due to GHRHR gene mutations, their final heights reached the parentally adjusted height, probably because of delayed puberty. This observation indicates that prolonged $\mathrm{GH}$ replacement in patients with severe GHD will be beneficial, even when the diagnosis is made at older ages.

\section{References}

1. Mullis P. Genetics of Isolated Growth Hormone Deficiency. J Clin Res Ped Endo 2010;2:52-62.

2. Martari M, Salvatori R. Chapter 3 Diseases Associated with Growth Hormone-Releasing Hormone Receptor (GHRHR)Mutations. Prog Mol Biol Transl Sci 2009;88:57-84. [Abstract] / [Full Text] / [PDF]

3. Cutfield W, A Lindberg, K Albertsson Wikland, $P$ Chatelain, MB Ranke, P Wilton. On behalf of the KIGS International Board. Final height in idiopathic growth hormone deficiency: the KIGS experience. Acta Pediatr 1999;428:72-75. [Abstract] / [PDF]

4. Rosenfeld RG, Cohen, P. Disorders of growth hormone/ Insulin-like Growth Factor secretion and action. In: SperlingMA (ed). Pediatric Endocrinology. 2ed. Philadelphia, Saunders, 2009;211-288

5. Salvatori R, Fan X, Phillips JA 3rd, Espigares-Martin R, Martin De Lara I, Freeman KL, Plotnick L, Al-Ashwal A, Levine MA. Three New Mutations in the Gene for the Growth Hormone (GH)-Releasing Hormone Receptor in Familial Isolated GH Deficiency Type IB. J Clin Endocrinol Metab 2001;86:273-279. [Abstract] / [Full Text] / [PDF]

6. Salvatori R, Hayashida CY, Aguiar-Oliveira MH, Phillips JA 3rd, Souza AH, Gondo RG, Toledo SP, Conceicão MM, Prince M, Maheshwari HG, Baumann G, Levine MA. Familial Dwarfism due to a Novel Mutation of the Growth Hormone-Releasing Hormone Receptor Gene. J Clin Endocrinol Metab 1999; 84:917-923. [Abstract] / [Full Text] / [PDF]

7. Wajnrajch MP, Gertner JM, Harbison MD, Chua SC, Jr, Leibel RL. Nonsense mutation in the human growth hormone-releasing hormone receptor causes growth failure analogous to thelittle (lit) mouse. Nat Genet 1996;12:88-90. [Abstract] / [PDF]
8. Martari M, Salvatori R. Chapter 3 Diseases Associated with Growth Hormone-Releasing Hormone Receptor (GHRHR) Mutations. Prog Mol Biol TransI Sci 2009;88:57-84. [Abstract] / [Full Text] / [PDF]

9. Hilal L, Hajaji Y, Vie-Luton MP, Ajaltouni Z, Benazzouz B, Chana M, Chraibi A, Kadiri A, Amselem S, Sobrier ML. Unusual phenotypic features in a patient with a novel splice mutation in the GHRHR gene. Mol Med 2008;14:286-292. [Abstract] / [Full Text] / [PDF]

10. Baumann G, Maheshwari H. The Dwarfs of Sindh: severe growth hormone $(\mathrm{GH})$ deficiency caused by a mutation in the $\mathrm{GH}$-releasing hormone receptor gene. Acta Paediatr Suppl 1997;423:33-38. [Abstract]

11. Alatzoglou KS, Turton JP, Kelberman D, Clayton PE, Mehta A, Buchanan C, Aylwin S, Crowne EC, Christesen HT, Hertel NT, Trainer PJ, Savage MO, Raza J, Banerjee K, Sinha SK, Ten S, Mushtaq T, Brauner R, Cheetham TD, Hindmarsh PC, Mullis $\mathrm{PE}$, Dattani MT. Expanding the Spectrum of Mutations in GH1 and GHRHR: Genetic Screening in a Large Cohort of Patients with Congenital Isolated Growth Hormone Deficiency. J Clin Endocrinol Metab 2009;94:3191-3199. [Abstract] / [Full Text] / [PDF]

12. Wajnrajch MP, Gertner JM, Sokoloff AS, Ten I, Harbison MD, Netchine I, Maheshwari HG, Goldstein DB, Amselem S, Baumann G, Leibel RL. Haplotype Analysis of the Growth Hormone Releasing Hormone Receptor Locus in Three Apparently Unrelated Kindreds From the Indian Subcontinent With the Identical Mutation in the GHRH Receptor. American Journal of Medical Genetics 2003:120:77-83. [Abstract] / [Full Text] / [PDF]

13. Oliveira HA, Salvatori R, Krauss MP, Oliveira CR, Silva PR, Aguiar-Oliveira $\mathrm{MH}$. Magnetic resonance imaging study of pituitary morphology in subjects homozygous and heterozygous for a null mutation of the GHRH receptor gene. Eur J Endocrinol 2003;148:427-432. [Abstract] / [PDF]

14. Salvatori R, Hayashida CY, Aguiar-Oliveira MH, Phillips JA $3^{\text {rd }}$, Souza AH, Gondo RG, Toledo SP, Conceicão MM, Prince M, Maheshwari HG, Baumann G, Levine MA. Familial Dwarfism due to a Novel Mutation of the Growth Hormone-Releasing Hormone Receptor Gene. J Clin Endocrinol Metab 1999; 84:917-923. [Abstract] / [Full Text] / [PDF]

15. Hiralal G, Maheshwari, Bernard L, Silverman, Josée Dupuis, Gerhard Baumann. Phenotype and Genetic Analysis of a Syndrome Caused by an Inactivating Mutation in the Growth Hormone-Releasing Hormone Receptor: Dwarfism of Sindh. J Clin Endocrinol Metab 1998;83:4065-4074. [Abstract] / [Full Text] / [PDF]

16. Grumbach MM, Bin-Abbas BS, Kaplan SL.The growth hormone cascade: progress and long-term results of growth hormone treatment in growth hormone deficiency. Horm Res. 1998; 49:41-57. [Abstract]

17. Edward O. Reiter, Kenneth M. Attie, Thomas Moshang, Jr, Bernard L, Silverman, Stephen F, Kemp, Rachel B, Neuwirth, Kathleen M. Ford, Paul Saenger and for the Genentech Inc.-Alkermes Inc. Collaborative Study Group. A Multicenter Study of the Efficacy and Safety of Sustained Release GH in the Treatment of Naive Pediatric Patients with GH Deficiency The Journal of Clinical Endocrinology \& Metabolism 2001: 86:4700-4706. [Abstract] / [Full Text] / [PDF] 